\title{
ENTREPRENEURIAL EDUCATION FOR STUDENTS OF NON-ECONOMICS EDUCATIONAL PROGRAMS
}

\author{
Ivan Štefanić, Goran Šimunović, Edita Štefanić, Ronald K. Campbell
}

Original scientific paper

Entrepreneurial skills are necessary for all graduates who are planning their own start-up business. Those skills are asked more and more by employers, even from fresh graduates of technical backgrounds. This paper compares two extracurricular programs involving students of four different, all noneconomics programs from Croatia and the USA. Several challenges were identified during the research. Preparing and executing entrepreneurial educational programs for students with very uneven level of relevant foreknowledge was one of them. Integration of classroom and e-learning methods and achievement of an effective combination of being educational, interesting and attractive in the same time were additional challenges. Gender of the participants, previous education, entrepreneurial background of their families and immediate plans upon the graduation were determined as influencing variables on their satisfaction with the program.

Keywords: business idea generation; business planning; education; entrepreneurship; students

Poduzetnička izobrazba studenata ne-ekonomskih obrazovnih programa

Izvorni znanstveni članak

Poduzetničke vještine su nužne svim diplomantima koji planiraju pokrenuti vlastito poduzeće. Dodatno, te vještine sve više traže i poslodavci, čak i od diplomanata tehničke izobrazbe. Ovaj rad uspoređuje dva ekstrakurikularna programa u koje su bili uključeni student četiri različita ne-ekonomska obrazovna profila iz Hrvatske i SAD. Tijekom istraživanja je identificirano nekoliko izazova. Priprema i izvršavanje poduzetničkog obrazovnog programa za studente s vrlo različitom razinom relevantnih predznanja je jedan od njih. Integracija nastavnih metoda iz učionice s 'distance learning' metodama postizanje učinkovite ravnoteže pristupa 'biti edukativan' i 'biti zanimljiv i atraktivan' predstavljaju dodatne izazove. Spol sudionika edukativnih programa, prethodna izobrazba, poduzetničko iskustvo njihovih obitelji i neposredni planovi nakon diplomiranja su identificirani kao utjecajne varijable na njihovo zadovoljstvo programom.

Ključne riječi: generiranje poslovne ideje; izobrazba; poslovno planiranje; poduzetništvo; student

\section{Introduction}

Identification of feasible, competitive, sustainable and ecologically sound business opportunities, know-how how to transform a business idea to fully developed business plan and the ability to work in interdisciplinary and frequently cross-cultural teams are some of the prerequisites that employers ask more and more, even from fresh graduates of technical background. Universities can address that issue in several ways, ranging from offering one synthetic, entrepreneurial course up to portfolio of several complementary entrepreneurship and economics courses. Karimi et al. [17] confirmed that the appropriate education has a significant effect on the students' abilities to generate improved innovative business ideas compared to the control group. The need for graduates who are prepared for employment and skilled in teamwork has been widely advocated. Zainal [27] and Radišić \& Nedeljković [20] advocated that a business case study solving approach is deeply needed for students. Investigation of Dunne at al. [8] conducted in Britain outlines a rationale for the development of group work in higher education. They point out that it is not enough to give the idea to the students about potential of the teamwork, but also to teach them about the difficulties of teamwork. But not all students can be taught in the same way. Study of Hill et al. [11] indicates that it is reasonable to expect differences in learning amongst students with different disciplinary backgrounds and nationalities.

Global Entrepreneurship Monitor - GEM monitors regularly entrepreneurial activities at the global level. Croatia was included into the pool in 2005 and in that particular year it was ranked as a last one according to the total entrepreneurial activities. In addition to that Croatian entrepreneurs were starting their business mostly due to the necessity and not due to the recognized entrepreneurial opportunity. Moreover, spatial distribution was extremely uneven, Lika and North-eastern Croatia were regions that were substantially lagging behind the national average. Ever since, certain improvements were made, but improvements were not sufficient to decrease regional differences (Singer, [21]). Several initiatives in the region were designed and executed to promote entrepreneurship and increase the number of small and medium enterprises. Centre for entrepreneurship in Osijek, NOA - savings and loan cooperative, BIOS incubator, and TERA TEHNOPOLIS - Business development and technology transfer centre of the Josip Juraj Strossmayer University of Osijek were founded to make the region more entrepreneurial and competitive. 'Be the Role Model' is the program established in 2005 to train the students in writing business plans. As the program grew, supporting staff developed even more efficient support materials including more comprehensive and more reliable templates and manuals, an online application for writing business plans and finally an effective mentoring program, during and after the competition (Štefanić, [23]).

\section{Materials and methods}

Two different, extracurricular, entrepreneurial programs were prepared and executed in 2015 with participants from four different educational programs from Croatia and USA. Both programs were designed to 
provide relevant knowledge and skills for selfemployment and to increase self-esteem of participants. The target audience were students of non-economics programs with various level of foreknowledge in economics and entrepreneurship topics.

Educational programs were based on the concept of Innovative $^{3}$ Entrepreneurship (Štefanić, [23]) and Assertive law for busy people (Campbell, [4]). Students participated in a series of lectures, TOPSIM business simulations, individual and team assignments, presentations and field trips. All participants generated feasible and competitive business ideas. Administration and continuous assessments of students were done with the help of the Moodle project for American participants and Merlin, a Croatian customization of Moodle software for Croatian participants.

Socio-economic variables for all participants were collected along with the statements regarding their immediate plans upon completion of their current academic programs (1-further education; 2-job seekers; 3startups; 4-job seekers with plans for further education; 5next generation of family business and 6-start-ups with plans for further education).

After the completion of the program all participants made a written evaluation assessing the success of the educational program in quantitative and qualitative ways as follows. Quantitative assessment - a numerical grade on a metric scale of 1-least successful to 5-most successful for: portfolio of course topics was appropriate; course materials were informative and available on time; student-teacher interaction was efficient; instructors were well prepared; instructors explained difficult materials well; the interaction among remote classrooms was efficient; course venue was appropriate; course improved perception of self-employment; portfolio of course topics was appropriate (data not shown) and overall grade of the course.

Qualitative assessment allowed each participant to say in open format what in his/her opinion was good in the course, what he/she would add or change in the course, would they recommend the course to other students, and why. Qualitative analysis includes comments given by course instructors, and the IT technicians as well.

Multivariate analysis (canonical correspondence analysis - CCA) was conducted to investigate their satisfaction level and differences among the groups. Data collection was made according to Czaja and Blair [6]. Ordination of plot data was constructed using Canoco 5 software (TerBraak \& Šmilauer, [25]) and restricted permutations were used in the Monte Carlo permutation test at 500 iterations. Canonical Correspondence Analysis allows presentation of the multivariate analysis in rather synthetic way where distances among group centroids and variables represent the strength of their correlation.

\section{$2.1 e^{4}$ corner@mefsb - entrepreneurship in engineering education initiative - key to better employability}

Project partners, Croatian Employment ServiceRegional office Slavonski Brod, Croatian Chamber of Economy Slavonski Brod County Chamber, Industrial
Park Nova Gradiška Ltd, Technology Development Centre - Development Agency of the Brod-Posavina County Llc and Institute for the Development of Education, together with associate partners: Holding "ĐuroĐaković" Llc, Student Council and MEFSB ALUMNI club decided to facilitate the growth of an employment in the Brod-Posavina County by strengthening the entrepreneurial competencies of unemployed mechanical engineers and engineering students. A specially designed educational program supported by the web portal 'e $\mathrm{e}^{4}$ corner@mefsb' was developed to facilitate learning in seminars and autonomous learning, Lifelong Learning Desk and extensive networking 'Enterprise Learning Partnership' were cornerstones of the initiative aiming to increase the number of start-ups in the region based on knowledge and technology.

The entrepreneurial education program was prepared and executed within the EU project ' $\mathrm{e}^{4}$ corner'. Students from Mechanical Engineering Faculty in Slavonski Brod (MEFSB) and students of the Faculty of Agriculture in Osijek - vocational program 'Agricultural entrepreneurship' from Vinkovci (FAOS) were participating in a series of workshops held in Slavonski Brod and Osijek. All participants, 9 from MEFSB and 18 from PFOS, generated innovative business idea and prepared fully developed business plan and a 3 minutes pitch which was delivered before the jury panel.

\section{2 'TransAtlantic' Entrepreneurial and Agribusiness Law seminar}

The 'TransAtlantic' program was a joint venture of the North Carolina State University from Raleigh, North Carolina (NCSU) and the Josip Juraj Strossmayer University of Osijek, Croatia (UNIOS). The program of the course was designed to integrate face to face and videoconferencing learning environments with an elearning platform for cross-cultural entrepreneurial education in two remote classrooms $8000 \mathrm{~km}$ and 6 hours' time difference apart. Classroom in Raleigh with 16 participants and classroom Osijek with 23 participants were connected with audio and video links in real time. In addition to that, desktop contents were shared with the help of Bridge software. All together there were three instructors, one in the Raleigh classroom and two (an American and a Croatian one) in the Osijek classroom. All communication, reading, assignments, and presentations were in the English language.

Syllabus for this, five weeks course contained curricular topics relevant to any business in general, and agribusiness in particular and non-curricular topics designed to boost self-esteem and encourage students to explore self-employment as their future career. Offered topics were grouped as follows:

A) Curricular topics: description and assessment of the importance of laws for entrepreneurs; differences between civil and criminal law; dispute resolution options (litigation, mediation, arbitration); prevention of financial loss in a legal situation (prophylactic jurisprudence); appraisal of promises the courts must enforce and elements of an agreement; role of a business agent; 
partnership and corporations; construction of the financial structure of the business; differentiation of the intellectual property; and law in cyberspace and privacy.

B) Non-curricular topics: developing self-esteem; building language competencies; training for collaborative work; practicing for interdisciplinary and transnational networking; enhancing presentation skills; and application of distance learning tools.

\section{Results and discussion}

Although small and medium size enterprises' contribution to the employment and creation of GDP varies from country to country they represent the major part of many economies. In 2013 statistics for EU $28^{1}$ shows that $92,7 \%$ of companies were employing less than 10 employees. Data for Republic of Croatia are consistent with that finding, indicating $91,6 \%$ of such companies. It is reasonable to expect that educational systems would take this situation into account, but reality is somewhat different, and requests of employers for more entrepreneurial labour force are not fulfilled.

More enterprising society is an important priority for many governments. Introduction of more elements of enterprise into the educational programs at all levels, and new and innovative ways to deliver that content represent the great challenge for educators. Study of Jones and Iredale [14] analyses an UK summer school by comparing Traditional and Enterprise modes of learning. They suggested that enterprise education requires a different pedagogical approach and aims to improve the educational experience. It appears that traditional teaching is more appropriate to the needs of the 'old' economy while the enterprising approach seems to be more appropriate to the needs of the new and flexible market economy.

\subsection{Entrepreneurial education and immediate plans upon the graduation}

The demand to increase competences of graduated engineers for quality employment and self-employment is an imperative. Taking into consideration the already identified issues, $\mathrm{e}^{4}$ corner project aimed to address insufficient creation of jobs and a gap between supply and demand for knowledge and skills in the Brod-Posavina County with entrepreneurship not present in an appropriate manner in the educational programs in a formal and informal non-economic education and a lack of programs for lifelong learning and low connectivity of educational institutions and business. The project is focused on the improvement of (self)employment of mechanical engineers in the Brod-Posavina County by connecting education with labor market through Enterprise Learning Partnership and encouraging target groups for different ways of learning, mobility, entrepreneurship, creativity and innovation (Anonymous, [1]).

\footnotetext{
1 EUROSTAT online, (accessed on June 25, 2016)

http://appsso.eurostat.ec.europa.eu/nui/show.do?dataset=eip_pop1\&lang $=$ en
}

Students at MEFSB do not have any entrepreneurial modules during the undergraduate and graduate programs. Before the entrepreneurial education starts, they were asked about their immediate plans upon graduation. The same questions were given to the students of vocational program at FAOS who have had a strong portfolio of economics and entrepreneurship modules. Fig. 1 and Tab. 1 present the results for all $\mathrm{e}^{4}$ corner participants simultaneously.

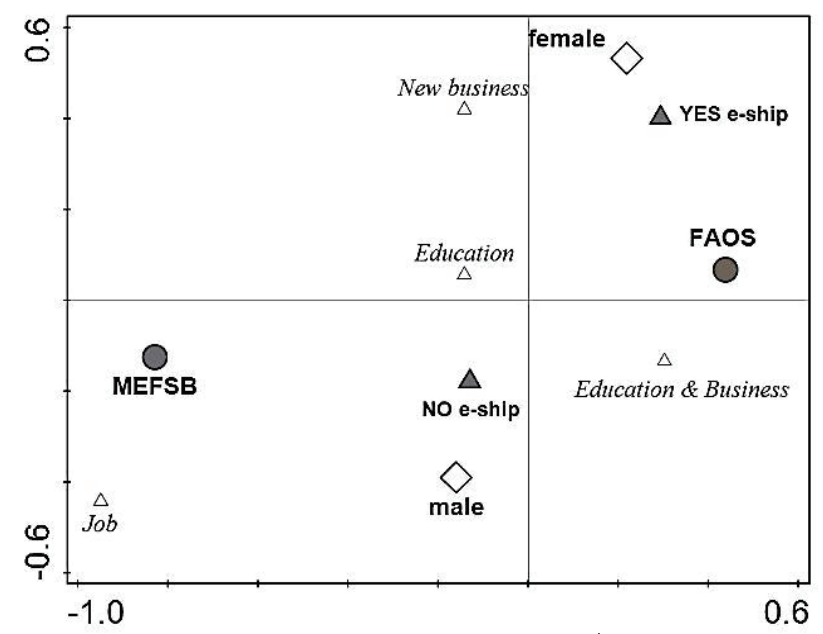

Figure 1 Immediate plans upon the graduation of ' $\mathrm{e}^{4}$ corner' participants

Canonical Function 1 explains $67,57 \%$ of the variations while Canonical Function 2 explains additional $32,39 \%$ of the variation. Total variation is 3,00000 , explanatory variables account for 13,3\% (adjusted explained variation is $1,5 \%$ ).

Table 1 Summary table of CCA 1 - Immediate plans upon the graduation of ' $\mathrm{e}^{4}$ corner' participants

\begin{tabular}{|l|c|c|}
\hline \multicolumn{1}{|c|}{ Statistic } & Axis 1 & Axis 2 \\
\hline Eigenvalues & 0,2700 & 0,0135 \\
\hline $\begin{array}{l}\text { Explained variation } \\
\text { (cumulative) }\end{array}$ & 9,00 & 13,31 \\
\hline $\begin{array}{l}\text { Pseudo-canonical } \\
\text { correlation }\end{array}$ & 0,5196 & 0,3597 \\
\hline $\begin{array}{l}\text { Explained fitted } \\
\text { variation (cumulative) }\end{array}$ & 67,57 & 99,96 \\
\hline
\end{tabular}

Permutation Test Results: On All Axes pseudo- $F=1,1 ; P=0,358$

Results show that MEFSB educate future male employees whose families do not have an entrepreneurial background. In addition to that, those students do not plan to start their own businesses upon graduation. On the other hand, FAOS educated students, which are more susceptible to the idea of starting their own business, are coming in a considerable proportion from the family businesses, mainly agribusinesses. In addition to that FAOS students' plan to continue their education simultaneously with their employment or entrepreneurial activities. It is important to emphasize that considerable proportion of FAOS students were female students.

The same questions were given to the TransAtlantic seminar participants. Results indicate that differences regarding the entrepreneurial background of the students' families and genders are much lesser. Having in mind that NCSU educate in that particular vocational program mostly future generations of existing agribusinesses, close 
proximity of NCSU group centroid to family business variable is understandable. On the other hand, finding a job and studying as a part-time student is more frequent among UNIOS graduates. Interestingly, results of the analysis do not support widely spread assumption of American students as more entrepreneurial than their European peers. This can be partially explained with the fact that seminar participants from UNIOS were mostly graduate students with more elaborated future plans compared to their American colleagues who were mostly undergraduate students.

Participants' feedback regarding the course satisfaction is shown for both programs jointly in Fig. 3. Again, entrepreneurial background of the family and participants gender plays the most important role. Canonical Function 1 explains 78,62 \% of the variations while Canonical Function 2 explains remaining 21,38\% of the variation.



Figure 2 Immediate plans upon the graduation of 'TransAtlantic' participants

Table 2 Summary table of CCA 2 - Immediate plans upon the graduation of TransAtlantic' participants

\begin{tabular}{|l|c|c|c|}
\hline \multicolumn{1}{|c|}{ Statistic } & Axis 1 & Axis 2 & Axis 3 \\
\hline Eigenvalues & 0,1918 & 0,0920 & 0,0365 \\
\hline $\begin{array}{l}\text { Explained variation } \\
\text { (cumulative) }\end{array}$ & 4,80 & 7,10 & 8,01 \\
\hline $\begin{array}{l}\text { Pseudo-canonical } \\
\text { correlation }\end{array}$ & 0,4380 & 0,3034 & 0,1912 \\
\hline $\begin{array}{l}\text { Explained fitted } \\
\text { variation (cumulative) }\end{array}$ & 59,87 & 88,59 & 100,00 \\
\hline
\end{tabular}

Permutation Test Results: On All Axes pseudo- $F=1,0 ; P=0,478$

Total variation is 4,00000, explanatory variables account for $8,0 \%$ (adjusted explained variation is $0,0 \%$ ).

Highest level of satisfaction is expressed by NCSU participants. In addition to that, it is important to emphasize that lowest satisfaction grade recorded in all surveys is 'good'. Total variation is 2,00000 , explanatory variables account for 10,3\% (adjusted explained variation is $2,7 \%$ )

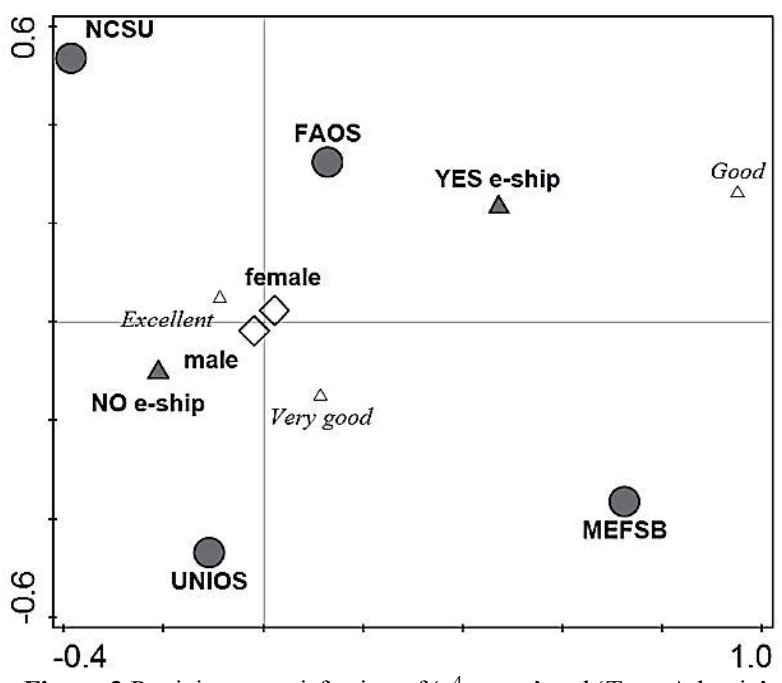

Figure 3 Participants satisfaction of ' $\mathrm{e}^{4}$ corner' and 'TransAtlantic' entrepreneurial programs

Table 3 Summary table of CCA 3 - Participants satisfaction of ' $\mathrm{e}^{4}$ corner' and 'TransAtlantic' entrepreneurial programs

\begin{tabular}{|l|c|c|}
\hline \multicolumn{1}{|c|}{ Statistic } & Axis 1 & Axis 2 \\
\hline Eigenvalues & 0,1619 & 0,0440 \\
\hline $\begin{array}{l}\text { Explained variation } \\
\text { (cumulative) }\end{array}$ & 8,10 & 10,30 \\
\hline $\begin{array}{l}\text { Pseudo-canonical } \\
\text { correlation }\end{array}$ & 0,4024 & 0,2098 \\
\hline $\begin{array}{l}\text { Explained fitted } \\
\text { variation (cumulative) }\end{array}$ & 78,62 & 100,00 \\
\hline
\end{tabular}

\subsection{Qualitative analysis of educational programs}

Importance of Enterprise modes of learning is in line with the findings of Chang et al. [5] who report that learning-by-doing enables students to develop their entrepreneurial skills and enhance their knowledge of social businesses. Students also became more effective in formulating and applying appropriate business strategies and team-work.

Making higher education more accessible to students who have been excluded and not only in entrepreneurial area is one of the major challenges of Higher Education Institutions in many countries. Some progress could be made by opening new schools. On the other hand, technological development can increase the use of online learning in Higher Education but that could represent the challenge for educators and their current practices (Jones and Lau, [15]).

If instructors wish to use web based instruction environment (WBI) three types of interaction are relevant for a learning process ${ }^{2}$. Study of Jung et al. [16] investigated the effects of those three interactions on learning, satisfaction, participation and attitude towards online learning in a WBI environment. The results indicate that social interaction subgroup has the best

2 A) Academic interaction includes interaction between learners and online resources as well as task-oriented interaction between learners and instructor. B) Collaborative interaction represents a group of learners who work collaboratively on a specific topic or share ideas and materials to solve a given problem. C) Social interaction between learners and instructors occurs when instructors implement strategies to encourage social integration. 
overall performance and the highest level of satisfaction with their learning experience was expressed by the collaborative interaction subgroup. In addition to that, the collaborative and social interaction subgroups participated more actively in posting their opinions than the academic interaction subgroup. Social interaction with instructors and collaborative interaction with peers appeared to be important for enhancing learning success and intensive participation in online discussion, even for adult learners.

Qualitative analysis is based on three open-ended questions: what was good in the course; what participants would like to add or change in the course; would they recommend the course to their fellow students and why; and are there any additional comments they would like to give after completion of the course. Numbers in parentheses after statement refer to number of course participants who made such a selection). Total number of participant is 66 .

What students found good in the course?

Opportunity to work in international and interdisciplinary teams (25), law content (10), preparedness and accessibility of the teachers (10), atmosphere, communication and vibes in the classrooms (15), field visits (4), learning about other country and mutual comparison (3), team building exercise at the beginning of the course (9), supporting materials (3), real life entrepreneurial cases (13), increased self-esteem (2) and possibility to present own business idea. In addition, Croatian students (4) highlighted the chance to practice communication in English as a very important and valid part of the course.

What students would like to add to the course?

More team work, debates, games, mock trials and comparisons (20), more field trips (4), more entrepreneurial content (6), more Croatian Law (1). In this section, 34 participants considered no additions to the course as necessary.

What students would like to change in the course? Less presentations and videos (3), more time for assignments (2), more in-depth content (2), longer course (4), improvement in connection technology (2), shorter course (1), less quizzes (1), versatile homework (1), delivering student presentations later in the program (1), revision of the student presentation before actual presentation (1), and inconvenient hours of the course (1). In this section, 42 participants stated no changes in the course are necessary.

Participants' readiness to recommend the course to their fellow students is considered as a measure of their satisfaction with the course. All participants stated they would recommend the course to other students. However, their recommendations have diverse reasoning. In most cases, it is because they experienced learning in a different way and considered it useful for their future (international) career. They refer to the course in very interesting terms: unique experience, inspiring, cool, enjoyable, great, exploration of the world without leaving the classroom, fun, and interesting. Reasons to recommend the course were the following: practical legal knowledge, improved presentation skills, working in cross-country and interdisciplinary teams, elevated selfesteem, improved English language (for Croatian participants), new friends, and networking.
Comparison of students' and teachers' evaluations indicates strong coherence of the evaluations. Students' evaluations were very detailed and mature. Preparation and execution of the course were challenging and time consuming for the teachers involved, but in the end they all agreed that the course was an invaluable experience. The experience of teaching the pilot course together along with the results of the course evaluations, represents a strong base for improvement, possibly with the use of a new e-learning platform and with different topics.

\subsection{Entrepreneurial education for non-economists}

Regardless of the way the entrepreneurial education program is organized and delivered, satisfaction of the participants play an important role for a success of the education as reported by Tarrant [24], 1984 who recorded a general high level of satisfaction with introductory level entrepreneurial courses in Somerset named 'Start your own business'.

State-of-the-art in the field of ICT-supported teachings is comprised of a large variety of rather diverse concepts and investigations. Some authors, like Bell and Bell [2], would emphasize the importance of support for senior staff to achieve an effective spread of innovation throughout the educational system. On the other hand, authors like Zhao and Frank [28] would compare educational and ecological systems and define teachers as the most influential "species" within an educational ecosystem, making the claim that they will never be replaced by ICT. In the end, much depends on the actual participant's perception of satisfaction with the educational program itself. Many policy makers, scholars, and practitioners in higher education use "distance education" and "e-learning" in higher education settings as synonyms. But the fact is that distance education in most higher education institutions is not delivered through the new electronic media. On the other hand, E-learning in most universities and colleges is not used in distance education. Distance education and e-learning do overlap sometimes, but they are not identical. (Guri-Rosenblit, [10]).

Ernest et al. [9] set up and piloted a small-scale professional development program by two universities. The aim was the development of experiences in language teaching through online group work. Additional goals include the implementation of a pilot project that would raise awareness of factors contributing to successful collaborative online activities, and the identification of professional development needs in this area. Planning and managing the collaboration, choosing the right environment and appropriate tools, designing appropriate activities, moderating at the right level, giving clear instructions and getting students to negotiate ground rules for participation were found as influential factors. Although this study was conducted with language teachers, many of the findings could be relevant to other subject areas, especially those requiring collaborative skills like entrepreneurship.

Smith et al. [22] compared two student subgroups of the same graduate course, work experiences in online (OL) and face-to-face (f2f), to determine what factors influence student group work experiences. 
Communication issues and personal feelings about group members and their participation play a considerable role in student perceptions about group work. Students in OL subgroup were more negative about group work than their counterparts in $\mathrm{f} 2 \mathrm{f}$ subgroup. OL students were less satisfied with group work because of individual and asynchronous work in their respectable group. Due to fewer channels of communication, the lack of immediacy of $\mathrm{f} 2 \mathrm{f}$ meetings, and some other factors, OL students were less able to work in the group effectively.

Use of ICT in teaching has a strong capacity to influence student evaluation of an educational program. A study conducted by Martin et al. [19] investigated how physical attendance affects students' evaluation of the lecturers. Students' attendance at lectures, the year, and class grade, and lecturer degree, were determined to affect students' evaluation of lecturers in a positive way.

On the other hand, a study by Winchester and Winchester [24] showed that students are more inclined to comment on negative issues, rather than critically analyse positive ones. They also tended to be more positive towards completing evaluations if the lecturers were open to implement some of their suggestions in later lectures. The extent to which students profit from a university course depends on the lecturers' approach to teaching, with a student-focused approach being more supportive for student gains in competencies than a teacher-focused approach.

Research conducted by Kelly et al. [18] analysed the results of a multimethod evaluation of an e-learning course designed to teach clinical skills to student nurses. The students perceived the flexibility and the selfmanagement of this method of learning as positive. Some attitudinal differences based on gender and ages were recorded. In the end, the course should rather be complemented as a support in a "blended" model.

Biasutti [3] investigated student experience in a collaborative e-learning module utilizing an asynchronous e-learning environment. The analysis identified five factors perceived by students as positive: teamwork, cognitive, operating, organizing, and emotive/ethic with the presumption that teamwork, operating, organizing, and emotive/ethic should be improved. The aspects that were associated with satisfaction include: comparing ideas, collaborating, peer learning, sharing knowledge and skills to support each other, the usability of the platform, analysing and integrating different points of view, workload management, and group planning. The following aspects of the student learning experience that have to be improved in e-learning include: more collaboration between students; workload management in the group activities; more coordination and organization; and technical problems such as updating modifications. Use of game design elements and mechanics in non-game contexts has been used successfully in many web-based businesses to increase user engagement. This idea could also be used in web-based education as a tool to increase student motivation and engagement. Dominguez et al. [7] designed and built a gamification plugin for a well-known e-learning platform to verify those theories. Their findings suggest that students who completed the gamified experience got better scores in practical assignments and in overall score. However, those students performed poorly on written assignments and participated less in class activities, in spite of their initial motivation. HyoJeong and Bush [12] examined students' perception of collaborative learning, social presence, and overall satisfaction in a blended learning environment. It was established that (a) course structure, (b) emotional support, and (c) communication mediums were critical factors.

Knowledge, experience and new methodologies relevant for various types of businesses are important for risk reduction related with entrepreneurial start-ups. Participants' satisfaction with such educational programs is important as well as increase of self-esteem.

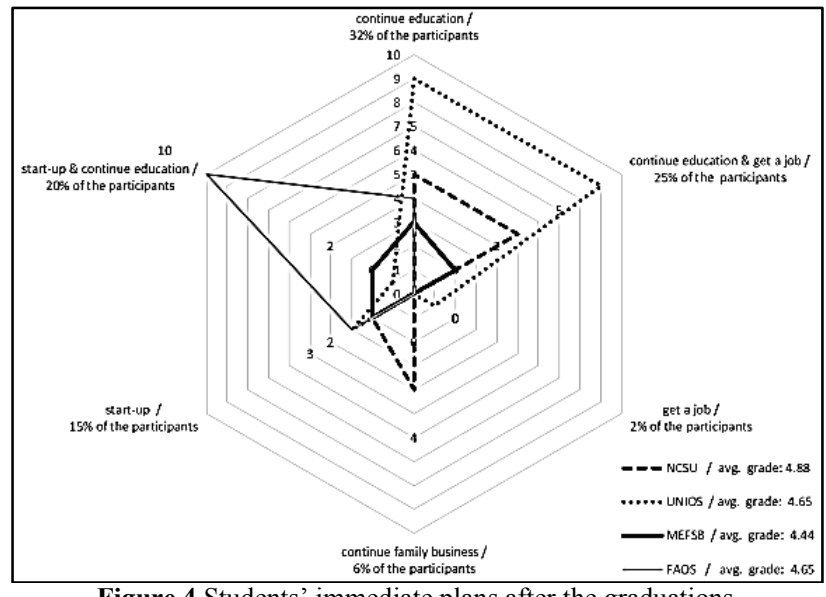

Figure 4 Students' immediate plans after the graduations

Both programs were designed to provide rather comprehensive set of relevant but not in-depth topics to future and even existing entrepreneurs. Additionally, entrepreneurial programs had to be useful for participants without immediate entrepreneurial plans. Fig. 4 shows the frequency of various participants' plans after graduation and average level of satisfaction with the entrepreneurial education program.

Experience collected from $\mathrm{e}^{4}$ corner and 'TransAtlantic' courses has wider applications, beyond the University domain. The increase in need for skilled human capital, vocational training and education could be covered through if e-learning has been widely adopted. It could serve as a major alternative for training and teaching professionals, technicians and students who cannot afford regular college education due to time, cost, and distance constraints. Inayat et al. [13] investigated the role of student-student and student-instructor interaction, support material, and instructor's feedback. The findings revealed that group work, team effort, instructor's feedback in a timely manner and consolidated support materials could enhance the learning experience of students and contribute positively to their learning success.

The most valuable and appreciated aspect of the 'TransAtlantic' course was the opportunity for live interaction across the divide. Leaders of tomorrow, especially in business as entrepreneurs must have a global vision, and 'TransAtlantic' participants agreed that collaboration improved this vision. Utilizing a common language is one of the key elements of joint educational programs in a blended learning environment. 'TransAtlantic' could have been between Portugal and 
Brazil in the area of medical education, or even 'TransPacific', but still, it would have been efficient.

\section{Conclusion}

Two experimental educational programs in entrepreneurship were successfully organized and executed for the participants with rather uneven educational background and entrepreneurial foreknowledge.

Educational program $\mathrm{e}^{4}$ corner, combined $\mathrm{f} 2 \mathrm{f}$ learning with use of business simulation TOPSIM and Moodle project support. All participants had an integrative assignment in the form of fully developed business plan and an 'elevator pitch' based on that business plan. Actual writing of the business plan was supported by templates in MS Word and MS Excel.

The 'TransAtlantic' seminar was particularly challenging, it was executed in two remote classrooms almost $8000 \mathrm{~km}$ and 6 hours' time difference apart, in Raleigh, North Carolina and Osijek, Croatia. In addition to that, the course was designed to integrate face to face and videoconferencing learning environments with an elearning platform for cross-cultural entrepreneurial education. Syllabus for this, five weeks course contained ten curricular topics relevant to any business in general, and agribusiness in particular, amended with six noncurricular topics designed to boost self-esteem and encourage students to explore self-employment as their future career.

Integration of classroom and e-learning methods was achieved and participants expressed their satisfaction with the design of the seminars. Instructors were successful in effectively delivering educational content in interesting and attractive way. Canonical correspondence analysis indicated influence of gender of the participants, previous education, entrepreneurial background of their families and immediate plans upon the graduation on participants' satisfaction with the program. With the help of CCA it was possible to understand the differences in the portfolio of the topics requested by the groups with different immediate plans upon the graduation. This is also very important for the creation of the programs that are better fitted to the needs of the groups with special needs.

Students played an important role in the course execution and with that developed strong ownership of the course. Team assignments and presentations, classroom communication via different available platforms were addressed as a novel and very useful experience.

\section{References}

[1] Anonymous e4corner@mefsb: entrepreneurship in engineering education initiative - key to better employability. Project brochure, MEFSB, Slavonski Brod, 2015.

[2] Bell, M.; Bell, W. It's installed now get on with it! Looking beyond software to the cultural change. // British Journal of Educational Technology. 36, 4(2005), pp. 643-643. https://doi.org/10.1111/j.1467-8535.2005.00541.x

[3] Biasutti, M. The student experience of a collaborative elearning university module. // Computers and education. 57(2011), pp. 1865-1875. https://doi.org/10.1016/j.compedu.2011.04.006

[4] Campbel, R. K. Assertive law for busy people. Second edition, Kendall Hunt publishing company, Dubuque, IA, 2010.

[5] Chang, J.; Benamraoui, A.; Rieple, A. Learning-by-doing as an approach to teaching social entrepreneurship. // Innovations in education and teaching international. 51, 5(2014), pp. 459-471. https://doi.org/10.1080/14703297.2013.785251

[6] Czaja, R.; Blair, J. Designing surveys - a guide to decisions and procedures. Pine Forge Press - A Sage publication company, Thousands Oaks, Ca., London, New Delhi, 1995.

[7] Dominguez, A.; Saenz-de-Navarrete, J.; de-Marcos, L.; Fernandez-Sanz, L.; Pages, C.; Martinez-Herraiz, J. J. Gamifying learning experiences: Practical implications and outcomes. // Computers and education. 63(2013), pp. 380392. https://doi.org/10.1016/j.compedu.2012.12.020

[8] Dunne, E.; Rawlins, M. Bridging the gap between industry and higher education: Training academics to promote student teamwork. // Innovations in education and training international. 37, 4(2000), pp. 361-371. https://doi.org/10.1080/135580000750052973

[9] Ernest, P.; Guitert, C. M.; Hampel, R.; Heiser, S.; Hopkins, J.; Murphy, L.; Sticler, U. Online teacher development: collaborating in a virtual learning environment. // Computer assisted language learning. 26, 4(2013), pp. 311-333. https://doi.org/10.1080/09588221.2012.667814

[10] Guri-Rosenblit, S. 'Distance education' and 'e-learning': Not the same thing. // Higher education. 49, 4(2005), pp. 467493. https://doi.org/10.1007/s10734-004-0040-0

[11] Hill, F.; Tomkinson, B.; Hiley, A.; Dobson, H. Learning style preferences: an examination of differences amongst students with different disciplinary backgrounds. // Innovations in education and teaching international. 53, 2(2016), pp. 122-134. https://doi.org/10.1080/14703297.2014.961504

[12] Hyo-Jeong, S.; Bush, T. A. Student perceptions of collaborative learning, social presence and satisfaction in a blended learning environment: Relationships and critical factors. // Computers and education. 51(2008), pp. 318-336. https://doi.org/10.1016/j.compedu.2007.05.009

[13] Inayat, I.; ul Amin, R.; Inayat, Z.; Salim, S. S. Effects of Collaborative Web Based Vocational Education and Training (VET) on LearningOutcomes. // Computers \& education. 68(2013), pp. 153-166. https://doi.org/10.1016/j.compedu.2013.04.027

[14] Jones, B.; Iredale, N. Developing an entrepreneurial life skills summer school. // Innovations in education and teaching international. 43, 3(2006), pp. 233-244. https://doi.org/10.1080/14703290600618522

[15] Jones, N.; Lau, A. M. S. Blending learning: widening participation in higher education. // Innovations in education and teaching international. 47, 4(2010), pp. 405416. https://doi.org/10.1080/14703297.2010.518424

[16] Jung, I.; Choi, S.; Lim, C.; Leem, J. Effects of different types of interaction on learning achievement, satisfaction and participation in Web-based instruction. // Innovations in education and teaching international. 39, 2(2002), pp. 153-162. https://doi.org/10.1080/14703290252934603

[17] Karimi, S.; Biemans, H. J. A.; Lans, T.; Aazami, M.; Mulder, M. Fostering students' competence in identifying business opportunities in entrepreneurship education. // Innovations in education and teaching international. 53, 2(2016), pp. 215-229. https://doi.org/10.1080/14703297.2014.993419

[18] Kelly, M.; Lyng, C.; McGrath, M.; Cannon, G. A multimethod study to determine the effectiveness of, and student attitudes to, online instructional videos for teaching clinical nursing skills. // Nurse education today. 29, 3(2009), pp. 292-300. https://doi.org/10.1016/j.nedt.2008.09.004

[19] Martin, S. I.; Way, D. P.; Verbeck, N.; Nagel, R.; Davis, J. A.; Vandre, D. D. The Impact of Lecture Attendance and 
Other Variables on How Medical Students Evaluate Faculty in a Preclinical Program. // Academic medicine. 88, 7(2013), pp. 972-977. https://doi.org/10.1097/ACM.0b013e318294e99a

[20] Radišić, M.; Nedeljković, A. 5C Model - Business case study solving methodology. // New Educational Review. 27, 1(2012), pp. 19-30.

[21] Singer, S. et al. Global Entrepreneurship Monitor - 2014 global report. Global Entrepreneurship Research Association, 2015.

[22] Smith, G. G.; Sorensen, C.; Gump, A.; Heindel, A. J.; Caris, M.; Martinez, C. D. Overcoming student resistance to group work: Online versus face-to-face. // Internet and higher education. 14, 2(2011), Special Issue, pp. 121-128.

[23] Štefanić, I. Inovativno3 poduzetništvo (Innovative3 entrepreneurship). // University textbook, Josip Juraj Strossmayer University of Osijek / Tera Tehnopolis Ltd., Osijek, 2015.

[24] Tarrant, R. Analysis of the dissemination of information on Start your own business courses in Somerset. // Programmed learning \& educational technology. 21, 2(1984), pp. 116-120. https://doi.org/10.1080/1355800840210210

[25] TerBraak, C. J. F.; Šmilauer, P. CANOCO Reference Manual and CanoDrow for Windows User's Guide. Biometris, Wageningen and České Budějovice, 2002.

[26] Winchester, M. K.; Winchester, T. M. If you build it will they come? Exploring the student perspective of weekly student evaluations of teaching. // Assessment \& evaluation in higher education. 37, 6(2012), pp. 671-682. https://doi.org/10.1080/02602938.2011.563278

[27] Zainal, Z. Case study as a research method. // Journal Kemanusiaan. 9(2007), pp. 1-6.

[28] Zhao, Y.; Frank, K. A. Factors affecting technology uses in schools: An ecological perspective. // American Educational Research Journal. 40(2003), pp. 807-840. https://doi.org/10.3102/00028312040004807

\section{Authors' addresses}

Ivan Štefanić, prof. dr. sc.

Josip Juraj Strossmayer University of Osijek

TERA TEHNOPOLIS d.o.o.

Gajev trg 6, HR-31000 Osijek, Croatia

stefanic@tera.hr

Goran Šimunović, prof. dr. sc.

Josip Juraj Strossmayer University of Osijek

Mechanical Engineering Faculty of Slavonski Brod

Trg I. Brlić-Mažuranić 2, HR-35000 Slavonski Brod, Croatia

gsimunovic@sfsb.hr

Edita Štefanić, prof. dr. sc.

Josip Juraj Strossmayer University of Osijek

Faculty of Agriculture of Osijek

Kralja Petra Svačića 1d, 31000 Osijek, Croatia

estefanic@pfos.hr

Ronald K. Campbell, J. D.

North Carolina State University, Raleigh, NC

rkcampbe@ncsu.edu 